\title{
TOWARD A NEW ENERGY PARADIGM IN GEOGRAPHY: REVISITING THE CURRICULUM AND TEACHING PRACTICES
}

\author{
NATALIJA MAŽEIKIENĖ \\ Faculty of Social Sciences, Vytautas Magnus University, \\ Jonavos str. 66, LT-44191 Kaunas, Lithuania \\ E-mail address: natalija.mazeikiene@vdu.lt \\ ORCID: https://orcid.org/0000-0001-8029-4907

\section{ODETA NORKUTE்} \\ Education Academy, Institute of Education Research \\ Vytautas Magnus University, Jonavos str. 66, 44191 Kaunas, Lithuania \\ E-mail address: odeta.norkute@vdu.lt \\ ORCID: https://orcid.org/0000-0001-7265-8029
}

\begin{abstract}
Aim. The aim of the article is to investigate how energy topics are presented in the geography curriculum in Lithuania and how school geography becomes an educational response to the current global challenges related to energy production and consumption.

Methods. The article presents research using several methods: review of literature on energy geography and energy literacy, analysis of Lithuanian national curriculum for geography, content analysis of 32 geography textbooks for forms 6-12, expert interviews with 9 geography teachers.

Results. The empirical research reveals that the national curriculum and textbooks still represent the old energy paradigm with a profound focus on fossil fuel and nuclear energy resources. Meanwhile, the new energy paradigm is realised in the teaching of experienced and qualified teachers who, in addition to the new green energy economy, emphasise environmental and social issues of energy use.

Conclusions. The conclusions include observations on necessary changes in teaching energy geography: on the one hand, by revising the formal curriculum and textbooks and integrating concepts of energy literature and new energy developments; on the other hand, by initiating changes in primary and continuous teacher education. Professional development of teachers could include new energy topics, new teaching and learning sources (political debates in media, TV, strategic energy development documents), new teaching and learning strategies and methods.

Key words: energy geography, energy literacy, geography curriculum, geography textbooks, nuclear energy, school geography.
\end{abstract}




\section{INTRODUCTION}

$\mathrm{D}$ evelopment of energy literacy, acquisition of knowledge on energyrelated topics is considered as an important part of the school curriculum in science, environmental education and geography in General Programmes of Primary and Basic Education (Pradinio ir pagrindinio ugdymo bendrosios programos. Socialinis ugdymas, 2008) and General Programmes of Secondary Education (Vidurinio ugdymo bendrosios programos, 2010). It has been a subject of discussion among educational researchers and experts in education emphasising the need for teaching based on energy in geography classes and revealing the central role of this school subject in addressing current energy issues (Thoyre \& Harrison, 2016). Geography is often called 'a school subject for survival' because it is considered as a promising educational response to climate change and other environmental and social issues. When it comes to energy, geography is expected to develop energy literacy, sustainability skills and critical thinking to address the current challenges of energy production and consumption.

The research presented below aims to reveal how the topic of energy is taught in the geography curriculum in Lithuania and how teaching of energy geography at school creates prerequisites to approach the energy-related challenges by building relevant skills and competences. To achieve this goal, several methods were applied: review of literature on energy geography and energy literacy, analysis of the Lithuanian national curriculum for geography, analysis of geography textbooks, expert interviews with geography teachers.

\section{ENERGY EDUCATION AS A NEW EMERGING AREA OF SCHOOL GEOGRAPHY}

School geography takes over main concepts from 'energy geography' which is "the study of energy development, transportation, markets, or use of patterns and their determinants from a spatial, regional, or resource management perspective" (Calvert, 2016, p. 104). At the research level, energy geography includes the following tasks: monitoring energy supply-chain developments; identifying place-based factors, which explained observed spatial patterns of energy-sector investment; assessing environmental and economic risk, especially in the context of large scale nuclear energy development; understanding how energy technology diffuses within and between nations; and mapping regional variations in energy production, distribution and use (Solomon et al., 2004; Calvert, 2016). Energy literacy enables learners to assess energy-related decisions throughout their lives: as citizens with a "citizenship understanding" in the context of local, national and global decisions, as well as at a personal level, in the context of their daily life decisions. It is believed that "energy literacy" would help equip people to make more responsible energy-related decisions and actions at the individual and societal levels (for instance, to reduce energy consumption) (Van der Horst et al., 2016; DeWaters et al., 2013). To 
implement new energy policy decisions at the national and global levels (e.g. the introduction of renewable energy technologies, climate change measures), energy literacy becomes an educational foundation that can create social support. Thus, citizens, while making energy-related decisions at personal and societal levels, need scientific literacy (including technological and environmental literacy), problem-solving skills and social competences and abilities, i.e. ethical aspects and citizenship understanding.

Knowledge on energy embraces a broad area of topics including energy acquisition, energy generation, storage and transport as well as energy consumption and conservation. Measuring knowledge of energy among eighth-grade pupils in Pennsylvania, Bodzin (2012) distinguished three main areas of energy content: (1) Energy Acquisition - Renewable and Nonrenewable Energy Resources; (2) Dimension 'Energy Generation, Storage and Transport' covers knowledge on energy generation from different sources (coal, nuclear, natural gas, hydropower (water), petroleum (crude oil), knowledge on the environmental impact of electricity generation, knowledge about network of power transmission lines connected across the entire country; (3) Dimension 'Energy Consumption and Conservation' embraces topics of how energy is consumed during pupils' personal and household activities.

Together with this knowledge on energy, students are expected to gain spatial analysis, critical analysis and reasoning skills (Bodzin, 2012) allowing them to better understand the spatial distribution of energy networks, how energy is supplied, distributed, utilised and consumed in their country and different regions throughout the world. It is important to provide understanding about the importance of energy in all economy (lighting, heating, communications, industry, transport) and in households, and its significance in constituting todays urban industrialised society and serving as a background of contemporary lifestyles of citizens and consumers (ibid., 2012).

Besides economic aspects of the use of energy, environmental topics are underlined in education for energy literacy. The use of energy resources is one of the major factors affecting the environment. It explains why the need to combine energy economy and environmental topics in energy geography at school is highlighted. In this area of education, students learn about economic development in their country and worldwide by treating nonrenewable and fossil-based energy as resources releasing large amounts of carbon dioxide and contributing to global warming and revealing the role of renewable and sustainable energy resources in mitigating climate change. The topic of environmental issues of energy use helps to implement education for sustainability in school geography which seeks to educate and socialise new citizens, consumers and policymakers, who become advocates of alternative energy resources (Thoyre \& Harrison, 2016).

The topic of the use of nuclear energy in the context of geography is related to the topic of education for sustainability. When interpreting nuclear energy as a domain of energy geography, it is important for students to recognise the use of nuclear energy in the global economy and geopolitics; to understand 
how the entire global infrastructure of nuclear power is built, what countries and energy networks participate in and develop the nuclear power industry. It is also important to disclose how the use of nuclear energy is incorporated into a general picture of the common energy infrastructure of countries and regions. Looking at the use of nuclear energy as a global phenomenon, it is important to raise questions about the environmental impact of using nuclear energy for energy, which is one of the cleaner technologies (in terms of CO2), but the potential insecurity of the nuclear technologies and spent radioactive fuel are causing real and potentially severe damage to nature and humanity (catastrophes and disasters).

Analysing energy education, authors emphasise the significance of making sense of the environmental and human implications of our energy choices (Graybill, 2016). A new generation of geographers conceptualise energy as a social relation; the energy is viewed as a mediator of the human - environment relationship.

While teaching about energy at schools and universities, many pedagogical difficulties and didactic challenges are faced. Students may not find this topic very attractive and interesting - the students demonstrate frustration, apathy or even confusion (Huber, 2016). "...Once individuals or students are exposed to energy education, their reactions are often volatile and unpredictable - from emotional distress to hostile defensiveness. As someone who views education as ultimately an avenue towards political consciousness and empowerment, these kinds of reactions can be frustrating as a teacher." (ibid., p. 78) It deals with one of the complications of teaching energy geography: empirical complexity of nature of energy which is very rich, multifaceted and complex.

Seeking to overcome pedagogical challenges of teaching and learning energy topics, strategies of a new pedagogy are applied. School and university teachers integrate active learning strategies, "learning by doing," apply problem-based and inquiry-based learning, fieldwork and new technologies in geography: digital data and imagery, new media (Day, 2012), digital storytelling in combination with time-intensive teamwork and work with new technologies and computer programs (Graybill, 2016).

\section{ENERGY IN THE NATIONAL CURRICULUM FOR GEOGRAPHY}

In Lithuania, the geography curriculum is defined by the General Programmes of Primary and Basic Education (Pradinio ir pagrindinio ugdymo bendrosios programos. Socialinis ugdymas, 2008) and General Programmes of Secondary Education (Vidurinio ugdymo bendrosios programos, 2010), which identify the areas of activities divided into knowledge, skills and attitudes: orientation in the area and map, reading of geographical information, cognition of regions, cognition of the environment and geographical investigations, analysis of natural and social processes. Recommended topics are presented in line with these areas. It is worth pointing out that these topics are quite common and 
broad (e.g. "Energy Industry," "Global Economy," etc.); therefore, at the stage of implementation of the curriculum, the authors of the textbooks, teachers designing education plans in schools, preparing and selecting materials from textbooks and various sources (including media) can put a more particular content and, in the case under our analysis, the topics on energy, into the frame of these broadly formulated topics.

Such principles of construction of the national curriculum in geography provide opportunities to analyse energy and energy industry as the most important branch of economy both worldwide and nationwide, deeper explore political economy, economic and energy geography, where energy is a mediator in relationships between people and the environment. Grounding on the Calvert's (2016, p. 104) concept of energy geography, the energy-related context can be incorporated into many thematic areas, e.g. energy development, transport systems, market economy, consumption models and their impact on the environment, usage of natural resources etc.

It is worth noting that energy literacy is not directly named or defined in the national curriculum; nevertheless, systematic approaches allowing formation of skills in a chosen area and development of the dimensions of energy literacy formulated by DeWaters et al. (2016) (cognitive, affective and behavioural) are observed because a consistent transition further from the content of specific knowledge, e.g. what is energy, what part of national economies is constituted by each field of the energy sector, what are energy resources etc., as well as attitudes and behaviour formation are traced: these would be topics and tasks on geography education dedicated to the concepts of climate change and environmental issues, analysis of energy consumption, pollution, positive and negative aspects of the types of energy, etc.

\section{ENERGY IN GEOGRAPHY TEXTBOOKS: TAKING A LOOK AT COVERAGE OF NUCLEAR ENERGY}

After carrying out analysis of 32 Lithuanian geography textbooks for forms 6-12 (Bačkienè, Pundienè, Januškis, 2009a; Bačkienè, Pundienè, Januškis, V. 2009b; Česnavičius \& Gerulaitis, 2008/2007; Česnavičius et al., 2010/2008; Česnavičius \& Valančienè, 2008; Dijokienė, 2016; Gerulaitis et al., 2010 a; Gerulaitis et al. 2010b; Kynė et al., 2008a; Kynè et al. 2008b; Kynė et al., 2016; Kynė et al., 2015; Šalna et al., 2012a; Šalna et al., 2012b; Šalna et al., 2006; Šalna et al., 2009/2005a; Šalna et al., 2009/20005b; Šalna et al., 2014; Šalna \& Sapožnikovas, 2010/2006a; Šalna \& Sapožnikovas, 2010/2006b; Šalna et al., 2005a; Šalna et al., 2005b; Šalna et al., 2010a; Šalna et al. 2010b; Šalna et al., 2010c; Šalna et al., 2012; Šalna \& Tuskenienė, 2009a; Šalna \& Tuskenienė, 2009b; Valančienė \& Česnavičius, 2008; Valančienė \& Dijokienè, 2007; Varanavičienè et al., 2017), the energy-related concepts and their illustration with examples have been found: energy resources, renewable and non-renewable resources, energy economy, social and environmental aspects of the use of energy sources and 
energy production. Such an approach to the construction of the content proves the concept-based teaching model designed by Gilbert (2006), where the concept is introduced through examples illustrating it. When acquainting with the concept of nuclear energy, textbooks develop the aspects of energy output and use which are supported with examples from different regions and countries: economic, geopolitical, environmental, social, militaristic, and technological progress. However, most of the attention is focused on the topic of economy: sources of energy, mining, and production of nuclear energy are discussed. Such examples as the increase of the consumption of nuclear energy over the last 50 years in the United Kingdom are presented, the list of countries running the largest amount of nuclear power plants (USA, Japan, France) is included, and the role and volume of the nuclear energy sector in the systems of global economy are emphasised (Česnavičius et al., 2010/2008). In the geopolitical point of view, nuclear energy is presented in the textbooks for forms 11-12 while discussing the militaristic use of nuclear energy, while the use of nuclear weapons during the years of the Second World War is episodically presented (Česnavičius \& Gerulaitis, 2008/2007). Another instance of the geopolitical aspect of the use of nuclear energy is displayed in the texts on the requirements for the closure of the Ignalina Nuclear Power Plant (Lithuania) in relation to the processes of entering the European Union as included in the textbooks for forms 10 and 11-12 (Česnavičius \& Gerulaitis, 2008/2007). Also, the social urbanistic aspect of energy production and consumption is presented in the textbooks; moreover, in the textbook for form 12, this aspect is illustrated with an example of Lithuania, where a town of Visaginas was constructed near the nuclear power plant and, after the closure of it, the town faced economic, social problems (ibid.) From the environmental point of view, nuclear energy is presented as not polluting the environment with $\mathrm{CO} 2$ particles; however, the texts reveal problem aspects, too: storing of nuclear waste which is hazardous to the environment; thermal effect of nuclear power plants on water bodies by increasing temperature causing changes in ecosystems; also, consequences of the Chernobyl disaster on people's health and the environment are identified (Česnavičius et al., 2010/2008; Gerulaitis \& Česnavičius, 2008/2007).

The conception of energy-grounded regions being formed in the textbooks helps school students understand the spatial patterns of the energy sector, when the energy economy comprises several different sources of energy, and nuclear energy constitutes an important part of national economies. The nuclear energy sector is discussed in interaction with other types of energy (coal, gas, water, thermal, and renewable resources) and, in such a way, students can form a more general concept of the energy economy.

Geography textbooks present various examples from regions and countries of the world illustrating energy-related concepts to students. These examples allow contextualising the content of geography curriculum and geography textbooks as well as providing preconditions for the formation of "focal events" as students' mental encounters with events presented in the content of geography curriculum. Focal events deal with occurred meaningful learning. 
These are the events which get attention and are put in the spotlight. The focal event is what appears to be learner's focus during a learning activity. The focal event refers to the personal, cognitive context shaped by the learner's personal interpretations of an activity. It is a result of contextualisation made by the students in the personal context of interpretations when students are actually trying to make sense of learning content in a net of interpretations of conceptual, situational and cultural contextual elements (Nilsson \& Iversen, 2008, as cited in Nilsson \& Ryve, 2010).

When dealing with the context-based approach in textbooks on geography, a very clear tendency, i.e. domination of introduction of economic energy consumption, is observed. The social aspect of energy consumption and energy sector is revealed through the relation to the explanation of the economic benefit or loss, discussing occupation or changes in the economic welfare. In the contemporary world, the environmental aspect gaining increasing relevance over the past decades is not sufficiently presented in detail, even though the textbooks analyse various topics on the environmental issues in relation to energy consumption; still, the overall volume of this topic is much lower than the economic topic of energy generation and use.

The majority of instances presented in the textbooks have been taken from other regions of the world, for example, the economic situations of regions (America, Asia, Europe, Australia) and single states (Russia, USA, China, Japan, Baltic States, Poland, United Kingdom, Republic of South Africa etc.) depending both on energy resources and energy production, which are quite distant from immediate and most familiar environment of students, are described in greater detail. Energy, electricity and fuel are fundamental to a contemporary mode of living; the energy sector determines quality of people's lives; nevertheless, texts in the geography textbooks, regrettably, pay little attention to energy consumption in the present-day world, the fundamental of a comfortable world and mode of living. There are no examples and tasks sufficiently relating the energy-focused content to the content which could be more familiar, closer to students (home and household, neighbourhood and immediate communities, local, regional and national context).

The textbooks discuss the historical development and change of nuclear energy, as a branch of industry. Most of the attention is focused on the concept of nuclear energy in geography textbooks for form 10 (Šalna et al., 2006; Valančienė \& Česnavičius, 2008), while quite extensively explaining the origination of nuclear energy in industry, the changes that were determined by this type of energy in the global economy, technologies, or lives of people. However, the general perception of nuclear energy is being formed consistently, starting from form 7 (Šalna et al., 2005a, 2005b), presenting the maps of uranium mines in texts; later, in form 8 (Šalna \& Sapožnikovas, 2010/2006a, 2010/2006b), the aspects of nuclear energy are linked to the cognition of regions, by presenting the number of nuclear power plants, volumes of production, consequences of the Chernobyl disaster. In forms 11-12 (Česnavičius et al., 2010/2008; Česnavičius \& Gerulaitis, 2008/2007) the analysis focuses on social and urbanistic mili- 
taristic, scientific and technical progress, geopolitical aspects of nuclear energy. The diversity of energy landscapes, technological, social changes related to energy mining and production is presented.

Another area which presents nuclear energy is the environmental aspect of energy in terms of potential insecurity of nuclear energy, its harm to people, nature, and the environment. This topic is developed by presenting catastrophes (Chernobyl disaster), radioactive pollution, potential insecurity of nuclear facilities, and problems of storing radioactive waste. Comparing the volume of discussions on this topic with the presentation of the economic aspect, the environmental aspect is given much less attention than the presentation of nuclear energy. The textbooks under our investigation do not introduce a new, contemporary approach to the area of nuclear energy, in terms of which nuclear energy is no longer treated as the only prospective area of economy because more attention in global economy, energy and political discourse is paid to renewable sources of energy, green economy, as the future trend.

It should be admitted with regret that Lithuanian schools use old textbooks (covering years 2005-2010); therefore, materials presented in them are outdated. Notions and instances presented when explaining the concepts of energy reduce the relevance of the presented content to students. Nevertheless, specific notions are suitable to explain a present situation (non-renewable and renewable sources of energy, assessment of the economic development level according to export of raw materials and processing of raw materials to products, etc.); however, particular illustrating examples, introduced events and processes, and information (diagrams, statistical data on distribution and mining of energy sources) are outdated. Texts or tasks in the textbooks make little appeal to the connections with current processes of the energy sector in Lithuania. Many present-day phenomena, which are relevant to Lithuania, are not reflected in these textbooks. Over the latter 15 years (since 2005, the year of publishing the oldest textbook that is presently used), many quite significant changes took place on the energy map of Lithuania. Introduction of relevant information in relation to the closure of the Ignalina Nuclear Power Plant is an exact example of outdated information at the scale of Lithuania because there is only the mentioning of the closure of the power plant about to start in 2009. All other relevant aspects are not dealt with and the current situation of energy production and consumption is not introduced, nuclear energy is no longer part of present-day and future energy landscape. Presently, a major document reflecting energy development, namely the Lithuanian National Energy Independence Strategy (2018), emphasises modern environmental, sustainable development aspects, such as thermal and electric production from renewable resources (biofuel, solar, biomass, geothermal), engagement of citizens in the field of energy production and consumption, which is directly connected to promotion of energy-focused participation and energy literacy education.

Grounding on the context-based approach, the described events, processes and instances should be as much as possible related to students' lives and topicalities: students should have an opportunity to recognise events introduced 
in the geography content as being close personally, to their own family, city or town, region, country. Only then is there a possibility for events discussed in the geography content to become focal events which are mentally constructed in the process of school students' learning. When carrying out tasks, i.e. analysing current relevant political, economic, and social events in public (media, TV), observing and analysing events and processes in their mundane lives, the immediate environment (e.g. processes taking place in neighbouring areas), identifying and analysing through action research, recognising in relationships with communities of practices (e.g. meetings with experts and through social interaction with other community members) students construct focal events in their consciousness and experiences. A task for form 7 formulated in relation to places in students' immediate surroundings which make impact on the environment, e.g. a factory in the neighbouring area, and data collected on the effect it makes on the environment, helps creating the physical-social aspect, could be an illustrating example. A task on explanation of the situation of Visaginas town and the Ignalina Nuclear Power Plant could be a similar task constructing a focal event on nuclear energy; however, this topic is scattered across separate topics (on energy, types of energy, foundation of settlements, Lithuanian economy) and different forms of students.

The analysis of geography textbooks pointed out a relevant problem question - how should a teacher use (or not use?) the textbooks if they are outdated? In the Lithuanian system of education holding limited financial resources, textbooks on geography are not being constantly updated, schools use old textbooks to save expense. Therefore, it is obvious that teachers can successfully implement objectives in teaching geography while using other resources, i.e. materials and tasks prepared by teachers and given to students or information found in media, on the Internet, television by students themselves, additionally to the textbooks. On the other hand, after carrying out analysis of the content of the textbooks and comparing with contemporary challenges of energy consumption worldwide, a question of a more general character occurs: what approach should be maintained in relation to preparation and use of textbooks in order they can meet the educational goals in relation to energy literacy. By applying the principles of context-based learning, the content of the textbooks should include contexts not only from other regions of the world, but also those introducing local, regional, national contexts which, with teacher's assistance, could be merged and integrated through investigation and projects into student's personal mundane, social activities.

\section{TEACHING ABOUT ENERGY: EXPERIENCES OF GEOGRAPHY TEACHERS}

Insights of 9 Lithuanian geography teachers have been used in the investigation. Geography teachers who have had exceptional experience in teaching geography were asked to be experts in this research. They were designers of 
the national geography curriculum, authors of geography textbooks, teachers who were awarded a highest professional category (teacher-expert), leaders and members of the national associations of teachers geographers and methodical associations, teachers who had long-term professional experience in teaching geography, conducting scientific research (writing doctoral dissertations), etc. among the research participants. Statements of the experts who took part in the investigation were coded and appear in the text as Expert 1-9.

The research was carried out in 2019. Before the arranged meetings, the research participants were given electronic forms of questions and, later on, both researchers met each expert for an individual interview. The researchers introduced the project in progress, EDUATOM ${ }^{1}$, dedicated to the designing of a non-formal education product, i.e. virtual educational nuclear tourism route in the region of Ignalina Nuclear Power Plant, to the experts. The researchers invited the experts to share their insights about the situation of energy literacy in geography lessons, development of the topic of energy in the geography curriculum, current presentation of nuclear energy, and possible teaching now and in the future, likely connections between formal and non-formal education when teaching about the energy sector within the school subject of geography. In their insights, teacher experts emphasised the aspects of the energy sector that could be important while introducing energy geography to and developing energy literacy: economic, geopolitical, social, environmental, in students. Teachers who participated in the interview illuminated general coverage of energy topics in geography classes and provided examples of teaching about nuclear energy.

\section{The Economic Aspect}

Similarly to the revealed findings in the analysis of the textbooks, insights of the experts focus much attention to the economic aspect. As the experts have it, the topic on energy is, first of all, related to industry and economy. Basically, this topic starts being developed since the teaching of geography commences in the sixth form and students get general acquaintance with branches of economy, energy production. Whereas students of forms 7 and 8 start getting acquainted with regions and prevailing energy sources in particular regions. In such a way, students learn about Latin America, Africa and Australia in form 7, and they learn about Europe, Asia in form 8 (Expert 1). Here, the following topics dominate: structure of industry, structure of global economy, energy sector (Expert 3, Expert 5, Expert 6). When introducing the content, the experts underline that the presenting of the topic on energy much depends on teacher's point of view, preparation, and attitudes. According to the experts, the topic "Energy Industry" indicated in the national programmes projects that

1 The research project 'The Didactical Technology for the Development of Nuclear Educational Tourism in the Ignalina Nuclear Power Plant (INPP) Region (EDUATOM)' is funded by the European Regional Development Fund according to the supported activity 'Research Projects Implemented by World-class Researcher Groups' under Measure No. 01.2.2-LMT-K-718 grant (No. 01.2.2-LMT-K-718-01-0084/232). 
a teacher should talk most of all about thermal, nuclear energy (Expert 8); but the expert does not mention the renewable resources. However, the research participants also point out that the conveying of the topic "Energy Industry" directly depends on teacher's preparation (Expert 6). The experts explicitly say that the topic of energy is not interesting to students: "not interesting, you know, it is displayed [in textbooks - authors' note] in a not very interesting way even to myself, bloodily uninterestingly displayed and include so many unclear things in relation to the energy sector" (Expert 5); therefore, a teacher must be well prepared, have competences to teach quite complicated material on energy in an interesting and attractive way because "when it's not interesting for yourself, you bring this message to children, too" (Expert 5).

The experts underline that the economic aspect in describing sources and industry of energy in textbooks is presented without providing any in-depth insights. They simply point out "energy sources (oil, nuclear energy), indicate where they operate, but this is characterised as a common branch of industry, without in-depth thinking and extensive analysis" (Expert 1). Through the geography subject, students could explore problem issues on importance of natural resources, limited possibilities of use and economic costs: "Why can't we fully use our local resources [oil, gas, because very low quantities of them are extracted - authors' note], perhaps they are too expensive"; and, in relation to the context of the Ignalina Nuclear Power Plant, students observe that the closure of the power plant causes negative economic consequences because "earlier we would sell [energy - authors' note], and now we purchase" (Expert 8), because when the INPP operated, Lithuania was a large exporter of electricity, and, after the closure, much of electric power is being imported.

The experts also recommend conducting with children in-depth analyses of decisions concerning energy production, i.e. wind, solar, water, geothermal water from the point of view of economic costs: how much equipment, exploitation cost, what economic benefit it brings (Expert 2). The experts comment on how the students' understanding of energy should be realised while working in class, as identified in the general programmes: students must be able to differentiate among the ways of energy use, resources, raw produce which are used in different regions; students "must be able to compare the resources of energy, to list advantages and disadvantages, to substantiate why particular countries use several sources of energy" (Expert 4). This demonstrates that the experts who took part in the investigation treat the concept of energy as a complex phenomenon which helps developing complex analytical, reasoning skills and developing energy literacy.

Introduction of nuclear energy is also related by the experts to the cognition of regions, when particular countries and branches of energy that are developed there, are singled out. In this topic, nuclear catastrophes (Chernobyl, Fukushima accidents) are discussed as well; however, the cognition of the economy and the region is not presented and investigated more extensively and in greater detail (Expert 1). The research participants consider the linking of energy as a branch of economy to the cognition of regions as very 
important and relevant - this allows teachers to find many good instances, reveal opportunities and threats of the energy sector. France is an example of a country that has high dependency on nuclear energy. Belgium may be discussed as a country which has little resources; therefore, it develops thermal energy at a larger extent. The Netherlands have become an example of a country which has much gas (Expert 6). It is important for students to understand the location of power plants, transportation and logistics goals. The location of enterprises and transportation costs reflect an important aspect of economy. Transportation costs for nuclear energy may be analysed in lessons by underlining that they are relatively small (when transporting nuclear fuel), which would be cheaper than transporting oil, liquefied gas (Expert 6). Nevertheless, it should be emphasised that the teacher experts talking about economic costs do not mention the costs of the closure of nuclear power plants, storing of nuclear fuel waste or liquidising the consequences of catastrophes, including human costs.

When talking about nuclear energy, the experts observe the historical context of occurrence of nuclear energy in Lithuania, which is treated as a Soviet legacy. Since the Ignalina Nuclear Power Plant was constructed in the Soviet period (started operating in 1983), it is obvious that it would be important for teachers to characterise this period and epoch during the lesson. As one of the experts has it, it would be relevant for students to know that "this is a construction of the Soviet period. That Griskkevičius [the Secretary of the Communist Party of Lithuania and the leader of the entire Soviet Republic of Lithuania at that time, both political and economic decisions made in Lithuania depended on him - authors' note] was ill with gigantism, that he was ill with gigantism and because of him we have everything what is the largest: the largest in the Baltic States, the largest in Lithuania, the largest in the Soviet Union" (Expert 3). The authors of the article can additionally point out that back then, when the INPP was built, it was the most powerful in the world.

\section{Social Aspects of Energy Generation and Consumption}

The experts describe social aspects of energy while mentioning satellite towns which were founded near large industrial plants. The research participants characterise the foundation of larger mono-industrial towns based on energy and other branches of industry in Lithuania in the Soviet period.

A social issue of energy is also disclosed through the urbanistic context: analysing how towns and communities form jointly with a separate branch of industry and economy (Expert 4). Analysing this subtopic, students find out about natural resources in particular regions and how these impact the development of towns or cities. The teachers participating in the research tell how they work with students: "we take a particular country and explore what industrial areas are there, how they are situated in the country, students find out in which towns or cities what kind of industry prevails" (Expert 1). It is noted that when discussing the content of the textbooks, the teachers experts observe that, from an urbanistic point of view, in the present content of geography textbooks, Visaginas is 
not given much attention: "Visaginas, as an industrial town, is mentioned within two lines, and that is all attention paid to it" (Expert 1).

It should be noted that the teachers directly relate social aspects to economy; more attention during lessons is paid to occupation, labour market, social divide, and inequality. Whereas the cultural specificity of cities or towns and communities is not singled out by the experts and it is not treated by them as important social issues connected to economic relations. When discussing the social aspect of the energy sector, the experts focused most of their attention on the instance of Visaginas and emphasised that this is still a topical problem for Lithuania. Until now, the closure of the INPP continues impacting the social structure and relationships in Visaginas (Expert 3). The research participants suggest topics that teachers should deal with when talking about the effect of the closure of the INPP on the mono-industrial satellite town Visaginas: "teachers should talk about the shock that was made by the closure of the INPP to Visaginas, its entire social environment. How many people lived there [before the closure of the plant - authors' note], what was the emigration [after the closure - authors' note], what was the percentage of unemployment, how the municipality tries to solve the issue of unemployment, how the financial means allocated for the closure of the INPP are being used, how much is allocated for education etc." (Expert 6).

The research discussed in the present paper involved 3 teachers of geography who were or are working in Visaginas. Their insights on delivery of energyrelated topics during geography lessons gives us quite interesting information. These participants of the research (experts) provided specific examples illustrating the delivery of lessons about the nuclear town facing social problems and challenges caused by the closure of the nuclear power plant in the subject of geography. In the course of lessons, teachers analyse functions (production, cultural, educational, trade, etc.) of mono-industrial towns or cities satellites operating near industrial objects and power plants and compare the situation of Visaginas with other towns or cities of Lithuania.-

As one geography teacher working in Visaginas, and also the participant of the investigation has it, the demolishing of the nuclear power plant is still creating economic activities to the town because "the town has some work. And even though it is hazardous, contaminated, people are working because they need to have jobs" (Expert 8). Here, the teacher means that the works of demolishing the power plant will continue until 2038 and longer. The teachers underline that the analysis of the national composition of Visaginas is of not lesser importance in lessons: "Visaginas is discussed, only in the framework of national minorities, because the issues of national composition, demography are covered" (Expert 1).

\section{Assessment of Environmental Impacts}

The experts list environmental issues related to the energy sector to be delivered during lessons on geography as a school subject. Both positive and negative aspects of energy production and consumption are underlined: "of course, there is a war against CO2; because we do not burn fossil fuel, less of it [CO2] penetrates the environment" (Expert 4); basically, nuclear energy is environment- 
friendly energy because there is no pollution as in a case of use of fossil fuel (Expert 8).

Moreover, it is important to reveal significance of renewable energy sourced during lessons: "when delivering the content, attention should be focused on significance of renewable energy sources and forming of a positive [students'authors' note] opinion" (Expert 6). As another expert has it, this topic on renewable resources was not reflected on in the old textbooks still being currently used in schools, and the theme of renewable resources appears in public political discourse only in ca. 2009; therefore, no surprise, if many teachers do not introduce this topic broadly (Expert 1). Also, they observe that this topic is still not developed in the textbooks and, accordingly, lessons because an approach stating that Western countries, such as Germany, the Netherlands, Belgium, represent the use of renewable energy sources (wind, water, solar) and East European countries continue being connected in the geography curriculum to the use of nuclear energy still dominates (Expert 1).

Another observation which has been found in the interviews of the experts, is that even though nuclear energy is economically favourable to the environment due to low air pollution, still one should be aware of catastrophes and assess it, since many countries undergo long-lasting effects of the catastrophes on their environment, or inhabitants (Expert 1). Nevertheless, some teachers analyse various types of power plants in various aspects of environmental protection: impact on atmosphere, water, soil and "what is safest for Lithuania and what priorities and choices should be and why?" (Expert 8).

One more important environmental aspect focuses on the storing of nuclear waste and potential threat to nature: "Canada, Russia, the USA bury [nuclear waste - authors' note] in the Arctic Ocean. These are huge contaminated zones. They are indicated, marked [in maps - authors' note]. These are death zones. But then we talk with children in a value-based approach: [discuss - authors' note] what is the effect on the ocean, what is the effect on us" (Expert 2). The aspect of storing nuclear waste is attributed to disadvantages of the nuclear energy sector (Expert 5); other analysed problems are the recycling of radioactive waste (Expert 8). Moreover, the experts emphasise that the aspect of burying nuclear waste is analysed in geography as consequences of economy activities (Expert 2). Here, a highly relevant example for Lithuania on what effect can be undergone from the burying of nuclear waste of the INPP is provided: "Lithuania is proud of its clean underwater. We are not South European countries which have no underwater suitable for drinking at all. So, if we bury [nuclear waste - authors' note], we will lose a possibility to have it [clean drinking underwater - authors' note]" (Expert 2).

Instances from the areas surrounding the INPP are mentioned among environmental problems, e.g. changes in the temperature of water of the lake on the bank of which the power plant was constructed or changes in the structure of the soil: "even though there were talks that seemingly there was no contamination, but, nevertheless, if the temperature of water changed, Drükšiai Lake would not freeze, and now [after the closure of the power plant - authors' note] it starts freezing. I had a chance to talk to people who said that soil [according to the chemical compo- 
sition in the environs of the INPP - authors' note] is equal to the composition of asphalt" (Expert 3).

Another aspect linked to environmental features relates to nuclear catastrophes. The experts note that the necessity to prepare for likely nuclear catastrophes can be found in the textbook materials: "the textbook writes that people must be prepared to all dangers. Must have means. Any signals must be broadcasted and familiar to them" (Expert 2). Also, a probability of a nuclear disaster is linked to natural geological conditions, and an example of the INPP is presented: the INPP has been constructed on a tectonic fault. This is explained by a serious error in projecting and constructing the nuclear power plant, which means that if the tectonic plates shift, the risk of an accident will increase (Expert 2).

The experts relate the explanation of the nuclear catastrophe in Chernobyl to the historical past - introduction of the Soviet period: "topics for form 8 dedicated to East Europe include two separate topics which deal with the disaster of the Chernobyl Power Plant. In this case students enjoy not exactly the historical context, because the name of Chernobyl is more or less familiar to all and how it relates, but it is interesting to them because we identify what damage was done, what factors for the country itself, what factors for residents. The textbook does not convey this information thematically, what we do in this case is based on teacher's initiative" (Expert 1). The expert working in Visaginas pointed out that lessons for form 8 include, in some detail, a discussion on Chernobyl, while analysing the causes in both technological and human aspects, also a discussion on the processes of liquidation, and raise problem questions: "after all, soldiers were the liquidators, what is their fate, where were they brought from, why was the information being kept in secret?" (Expert 8).

Talking on the nuclear energy sector in Lithuania, one more expert has it that another object of nuclear energy would be a more relevant topic and should receive more attention - the Astravets Nuclear Power Plant (in Belarus) being constructed near Lithuania: "[the INPP - authors' note] is already being closed, we no longer so strongly emphasise [this issue - authors' note] as relevant, we talk about threats of Astravets" (Expert 4); however, he notes that, when teaching geography to students himself, he emphasises the past opportunities or prospects, too, because, after the closure of the INPP in 2009, Lithuania, Latvia and Estonia planned to construct a new nuclear power plant; the "Hitachi" company was supposed to take part in the construction; therefore, the statement of the expert illustrates the necessity to be prepared to introduce the most important topicalities: "When there was that Hitachi project, there also were many talks about it". We should remark here that the plans to construct a new nuclear power plant according to the project suggested by "Hitachi" were given up after the referendum held in 2012.

\section{The Geopolitical Aspect in Energy Development}

All experts, more or less talking about the geopolitical aspects of the energy sector, mentioned the situation of the closure of the INPP, when Lithuania entering the EU had to assume a political obligation to close the power plant considered to be unsafe. It should be admitted that the reactors of the INPP 
are of the same RMBK model, like those of the Chernobyl NPP. This fact is presented in detail in the textbooks, too; therefore, the experts deliver the argument which is mentioned during the geography lessons.

A statement of one of the experts pointing out that a teacher in this area must have political knowledge, that geography alone is not enough because "without awareness of a political process [a teacher - authors' note] will surely not understand [how to properly convey it - authors' note]," how to develop energy literacy, what is currently relevant for Lithuania ensuring independence in the energy sector, can be mentioned as one of more interesting observations on the geopolitical aspects in relation to energy. The expert has it that obtained knowledge on political sciences helps better analyse the topical aspects with students: "together with students, we have discussions even on such matters like what is synchronisation [of electric power grids - authors' note], and they even are aware of these notions. There are no such notions in the textbook" (Expert 1).

One of the teachers who took part in the investigation provides a local example illustrating the geopolitical aspect of the INPP: the power plant was constructed very near Belarus and Latvia, which creates a significant geopolitical bond; therefore, it is important for a teacher to note and emphasise: "how we will cohabit with these countries" (Expert 2). Moreover, the value-based aspect is emphasised: students should be educated as "strong, resistant in terms of values," to critically assess diversity of information, which is related by the expert to the geopolitical literacy.

After asking the teachers experts about significance of delivery of energy literacy and energy geography, they all noted that it is important; however, teachers themselves lack energy literacy to teach energy geography (Expert 2). Teacher's possibilities to develop energy literacy are limited because, actually, they are not prepared for that, since they have no specific knowledge: "the theme is specific because geography teachers, as they have been trained and prepared, hold no knowledge of that" (Expert 1). Knowledge of geography teachers is oriented towards economic, industrial matters: "they hold knowledge only for presenting that this is a branch of industry, comprises specific units and operates mostly in specified countries, without any more extensive explanation; here, one needs to have political, economic perception" (Expert 1). Problems revealing that this area is not given importance in the subject of geography have been been identified, too: "energy literacy is allocated up to 10 per cent in volume of the entire content of geography," "energy literacy is not a priority in programmes, surely does not reach 10\% in the programmes" (Expert 1).

\section{CONCLUSIONS}

A review of the content of the national curriculum and textbooks as well as an analysis of interviews with the teachers experts revealed the components of energy geography in Lithuania. The topic of energy economy stands out as the most important in all three analysed levels of the curriculum (formal curricu- 
lum programmes, textbooks teaching practice).

It should be noted that the main emphasis on economic topics corresponds to how researchers and scholars analysing energy geography (Solomon et al., 2004, Calvert, 2016) talk about topics in this area: spatial patterns of energy-sector investment, regional variations in energy production, distribution and use, environmental and economic risks are mentioned. The assessment of the environmental impact and the social aspect are significantly less pronounced in the current planned and implemented geography curriculum. Therefore, we conclude that the new energy paradigm and new developments in green energy economy and addressing the challenges of climate change are not presented strongly enough.

It is noteworthy that the current content of the geography subject in Lithuania is determined by the formal curriculum programmes and textbooks prepared in 2008, which reflect the 10-15-year-old energy geography paradigm that focused on the orientation towards fossil fuel resources and nuclear energy. The newer textbooks issued in 2017-2018 are not widely used due to the fact that schools do not purchase them to save money. The renewal of the national curriculum will be carried out in Lithuania from 2020 and new textbooks will be prepared later on. It is likely that a new focus on green energy and renewables, assessment of environmental risks will be reflected there. Interviews with the teacher experts have shown that teachers are important agents in the implementation of the curriculum. Geography teachers with appropriate professional preparedness, pedagogical skills, awareness and civic attitudes incorporate a new approach into the subject of geography: they try to reflect the new strategic goals of the country's energy economy (restructuring of the energy sector after the closure of the nuclear power plant and the ongoing shift towards renewable energy and green energy, ensuring energy independence from external fossil fuel resources from Russia, introducing an environmental approach to energy).

In this context, the question arises on how to engage teachers in constructing curriculum and empower them by providing missing competencies. We would name some directions for the development of teachers' knowledge and skills. On the one hand, there is a need to improve the initial training of geography teachers by including more topics about energy. Another direction is to improve competencies of teachers working at schools, especially through self-directed learning by gaining knowledge about new energy developments from debates in public space (political discourse, TV, media), by getting acquainted with strategic energy development documents and relevant information, cooperating with other curriculum developers (universities, departments of the Ministry of Education and professional development centres), participating in professional associations of geography teachers. This collaboration, alongside professional development, would allow sharing teaching experience, initiating collaborative work on new national geography and textbooks. 


\section{ACKNOWLEDGEMENTS}

This article presents findings of the research project 'The Didactical Technology for the Development of Nuclear Educational Tourism in the Ignalina Nuclear Power Plant (INPP) Region (EDUATOM)'. This research is funded by the European Regional Development Fund according to the supported activity 'Research Projects Implemented by World-class Researcher Groups' under Measure No. 01.2.2-LMT-K-718 grant (No. 01.2.2-LMT-K-718-01-0084/232).

\section{REFERENCES}

[1] Bodzin, A. (2012). Investigating urban eighth-grade students' knowledge of energy resources. International Journal of Science Education, 34(8), 1255-1275, DOI: 10.1080/09500693.2012.661483

[2] Calvert, K. (2016). From 'energy geography' to 'energy geographies': Perspectives on a fertile academic borderland. Progress in Human Geography 2016, Vol. 40(1), 105-125.

[3] Day, T. (2012). Undergraduate teaching and learning in physical geography. Progress in Physical Geography 36(3), 305-332.

[4] DeWaters, J., Qaqish, B., Graham, M. \& Powers, S. (2013). Designing an energy literacy questionnaire for middle and high school youth. The Journal of Environmental Education, 44(1), 56-78, DOI: 10.1080/00958964.2012.682615

[5] Gilbert J. K. (2006). On the nature of "context" in chemical education. International Journal of Science Education, 28(9), 957-976, DOI: 10.1080/09500690600702470

[6] Graybill, J. K. (2016). Teaching energy geographies via videography. Journal of Geography in Higher Education, 40(1), 55-66, DOI: 10.1080/03098265.2015.1089474

[7] Huber, M. (2016). Teaching energy geography? It's complicated. Journal of Geography in Higher Education, 40(1), 77-83, DOI: 10.1080/03098265.2015.1089476

[8] Nacionalinè energetinès nepriklausomybès strategija, 2018 [National Energy Independence Strategy].

[9] Nilsson, P. \& Ryve, A. (2010). Focal event, contextualization, and effective communication in the mathematics classroom. Educational Studies in Mathematics, 74(3), 241-258.

[10] Pradinio ir pagrindinio ugdymo bendrosios programos. Socialinis ugdymas (2008) [General Programmes of Primary and Basic Education. Social Education]. Retrieved from: https://www. smm.lt/uploads/documents/svietimas/ugdymo-programos/6_Socialinis-ugdymas.pdf, accessed 15 April 2021.

[11] Solomon, B. D., Pasqualetti, M.J. and Luchsinger, D.A. (2004). Energy geography. In: Gaile G. and Willmott C. (eds.). Geography in America at the Dawn of the 21st Century. Oxford: Oxford University Press.

[12] Thoyre, A. \& Harrison, C. (2016). Introduction: teaching energy geographies. Journal of Geography in Higher Education, 40(1), 31-38, DOI:10.1080/03098265.2016.11325

[13] Van der Horst, D., Harrison, C., Staddon, S. and Wood, G. (2016). Improving energy literacy through student-led fieldwork - at Home. Journal of Geography in Higher Education, 40(1), 67-76, http://dx.doi.org/10.1080/03098265.2015.1089477.

[14] Vidurinio ugdymo bendrosios programos: socialinis ugdymas. (2010). Vidurinio ugdymo bendrujų programu 5 priedas [General Programmes of Secondary Education: Social Education. Annex 5 to the General Curricula of Secondary Education]. Retrieved from: https://www.smm.lt/ uploads/documents/svietimas/ugdymo-programos/vidurinis-ugdymas/Socialinis_ugdymas_5_priedas.pdf, accessed 15 April 2021.

\section{Sources:}

[1] Bačkienė, R., Pundienė, V., Januškis, V. (2009a). Geografija. 7 kl. 1-oji kn. (serija „Šok“). [Geography. For Form 8. Part 1. Set "Jump")]. Šviesa, Kaunas.

[2] Bačkienė, R., Pundienė, V., Januškis, V. (2009b). Geografija. 7 kl. 2-oji kn. (serija „Šok“). [Geography. For Form 8. Part 1. Set “Šok")]. Šviesa, Kaunas. 
[3] Česnavičius, D., Gerulaitis, V. (2008/2007). Bendroji geografija. Vadovèlis 11-12 kl. Trečioji knyga [General Geography. Textbook for Forms 11-12. Book 3]. Šviesa, Kaunas.

[4] Česnavičius, D., Gerulaitis, V., Kynè, G. (2010/2008). Regioninè geografija. Vadovèlis 11-12 klasei [Regional Geography. Textbook for Forms 11-12]. Sviesa, Kaunas.

[5] Česnavičius, D., Valančienè, E. (2008). Lietuva. Europa. Pasaulis. 10 kl. [Lithuania. Europe. World. For Form 9]. Šviesa, Kaunas

[6] Dijokienė, S. (2016). Geografija. Pasaulio ir Lietuvos ūkis. Mokymosi medžiaga 10 klasei [Geography. World and Lithuanian Economy. Study Materials for Form 10]. Ugda.

[7] Gerulaitis, Š., Bačkienè, R. (2009). Bendroji ir regioninè geografija 11 - 12 klasei. Antrasis pratybų sąsiuvinis [General and Regional Geography for Forms 11-12. Exercise Book 2]. Śviesa, Kaunas.

[8] Gerulaitis, Š., Kynè, G., Varanavičienè, G., Krušinskienė, R., Tamošiūnienė, D. (2010a). Geografija. 8 kl. 1-oji kn. (serija „Šok“). [Geography. For Form 8. Part 1. Set “Jump“)]. Šviesa, Kaunas.

[9] Gerulaitis, Š., Kynè, G., Varanavičienė, G., Krušinskienė, R., Tamošiūnienė, D. (2010b). Geografija. 8 kl. 2-oji kn. (serija „Šok"). [Geography. For Form 8. Part 2. Set “Jump“)]. Šviesa, Kaunas.

[10] Kynè, G., Kirilovas, V., Mikulienè, I., Žiuurienè. S. (2008a). Mūsų daug - pasaulis vienas. Geografijos vadovèlis $6 \mathrm{kl}$. 1-oji kn. (serija „Šok"). [There are many of us, but only one world. Geography Textbook for Form 6. Part 2 (Set "Jump")]. Šviesa, Kaunas.

[11] Kynè, G., Kirilovas, V., Mikulienė, I., Žiūrienè. S. (2008b). Mūsų daug - pasaulis vienas. Geografijos vadovèlis $6 \mathrm{kl}$. 2-oji kn. (serija "Šok"). [There are many of us, but only one world. Geography Textbook for Form 6. Part 2 Set "Jump“)]. Šviesa, Kaunas.

[12] Kynè, G., Ubartas, T., Šabanovas, S., Barauskienė, L. (2016). Geografija 7 kl. (serija „Atrask“) [Geography for Form 7. (Set "Discover")]. Šviesa, Kaunas

[13] Kynè, G., Varanavičienè, G., Railienè, L., Ubartas, T., Kamarauskaitė, A. (2015). Geografija. 6 k1. (serija "Atrask "). [Geography. For Form 6. (Set "Discover")]. Šviesa, Kaunas.

[14] Šalna, R. Baleišis, E., Baubinas, R., Daugirdas, V. (2012a). Žemè. Geografijos vadovèlis. 1 d. 9 k1. [Earth. Geography Textbook for Form 9. Part 1]. Briedis.

[15] Šalna, R. Baleišis, E., Baubinas, R., Daugirdas, V. (2012b). Žemè. Geografijos vadovèlis. 2 d. 9 kl. [Earth. Geography Textbook for Form 9. Part 2]. Briedis.

[16] Šalna, R., Baubinas, R., Mačiulytė, J., Padriezas, V., Tuskenienè, V., Žolynas, M. (2006). Žemè. Geografijos vadovèlis 10 klasei [Earth. Geography Textbook for Form 10]. Briedis.

[17] Šalna, R., Čepaitytė, G., Sapožnikovas, G. (2009/2005a). Žemė. Geografija. 1 d. 7 kl. [Earth. Geography Textbook for Form 7. Part 1]. Briedis.

[18] Šalna, R., Čepaitytė, G., Sapožnikovas, G. (2009/20005b). Žemè. Geografija. 2 d. 7 kl. [Earth. Geography Textbook for Form 7. Part 2]. Briedis.

[19] Šalna, R., Mačiulytė, J., Padriezas, V., Pakamorienė, A., Sapožnikovas, G., Tuskenienė, V., Žolynas. M. (2014). Žemè. Geografija. 10 kl. [Earth. Geography Textbook for Form 10]. Briedis.

[20] Šalna, R., Sapožnikovas, G. (2010/ 2006a). Žemè. Geografijos vadovèlis 8 klasei. I dalis [Earth. Geography Textbook for Form 8. Part 1]. Briedis.

[21] Šalna, R., Sapožnikovas, G. (2010/ 2006b). Žemè. Geografijos vadovèlis 8 klasei. II dalis [Earth. Geography Textbook for Form 8. Part 2]. Briedis.

[22] Šalna, R., Sapožnikovas, G., Čepaitytè, G. (2005a). Žemè. Geografijos vadovèlis 7 klasei. I dalis [Earth. Geography Textbook for Form 7. Part 1]. Briedis.

[23] Šalna, R., Sapožnikovas, G., Čepaitytė, G. (2005b). Žemè. Geografijos vadovèlis 7 klasei. II dalis [Earth. Geography Textbook for Form 7. Part 2]. Briedis.

[24] Šalna, R., Sapožnikovas, G., Motiejuitè, G., Šiumeta, M., Šalna, R. (2010a). Gamtinè geografija. Geografijos vadovèlis. 11 - 12 kl. (serija "Gaublys"). [Natural Geography. Geography Textbook for Forms 11-12. (Set "Globe")]. Didakta.

[25] Šalna, R., Sapožnikovas, G., Motiejuitè, G. (2010b). Žemė. Geografija. 1 d. 8 kl. [Earth. Geography for Form 8. Part 1]. Briedis.

[26] Salna, R., Sapožnikovas, G., Motiejuitè, G. (2010c). Žemè. Geografija. 2 d. 8 kl. [Earth. Geography for Form 8. Part 1]. Briedis.

[27] Šalna, R., Šalna, R. Šiumeta, M. (2012). Gaublys. Visuomeninè geografija. Geografijos pratybụ sąsiuvinis 11 - 12 klasei II dalis. [Globe. Social Geography. Geography Exercise Book for Forms 11-12. Part 2]. Didakta. 
[28] Šalna, R., Tuskenienė, V. (2009a) Žemè. Geografijos vadovèlis. 1 d. 6 kl. [Earth. Geography Textbook for Form 6. Part 1]. Briedis.

[29] Šalna, R., Tuskenienė, V. (2009b) Žemè. Geografijos vadovèlis. 2 d. 6 kl. [Earth. Geography Textbook for Form 8. Part 2].

[30] Valančienė, E., Česnavičius, D. (2008). Lietuva. Europa. Pasaulis. Geografija. Vadovèlis 10 klasei [Lithuania. Europe. World. Geography. Textbook for Form 10]. Šviesa, Kaunas.

[31] Valančienė E., Dijokienė S. (2007). Lietuva. Europa. Pasaulis. Geografija. 9 kl. [Lithuania. Europe. World. Geography for Form 9]. Šviesa, Kaunas.

[32] Varanavičienė, G., Krušinskienė, R., Šabanovas, S., Sakalauskienė, I. (2017). Geografija 8 klasei (serija "Atrask“) [Geography for Form 8 (set “Discover"). Šviesa, Kaunas. 